\title{
Effects of Poultry Manure and Biochar on Acrisol Soil Properties and Yield of Common Bean. A Short-Term Field Experiment
}

\author{
José Romualdo de Sousa Lima ${ }^{1, *} \mathbb{0}$, Maria da Conceição Cavalcanti de Goes ${ }^{1}$, Claude Hammecker ${ }^{2} \mathbb{D}$, \\ Antonio Celso Dantas Antonino ${ }^{3}$, Érika Valente de Medeiros ${ }^{1}$, Everardo Valadares de Sá Barretto Sampaio ${ }^{3}$, \\ Maria Camila de Barros Silva Leite ${ }^{1}$, Vanilson Pedro da Silva ${ }^{1}\left[\right.$, Eduardo Soares de Souza ${ }^{4}(\mathbb{C}$ \\ and Rodolfo Souza ${ }^{5}$ (D)
}

check for

updates

Citation: Lima, J.R.d.S.; Goes,

M.d.C.C.d.; Hammecker, C.;

Antonino, A.C.D.; Medeiros, É.V.d.; Sampaio, E.V.d.S.B.; Leite, M.C.d.B.S.; Silva, V.P.d.; de Souza, E.S.; Souza, R. Effects of Poultry Manure and Biochar on Acrisol Soil Properties and Yield of Common Bean. A Short-Term Field Experiment. Agriculture 2021, 11, 290. https://doi.org/10.3390/ agriculture 11040290

Academic Editors: Zakaria Solaiman, Hossain Md Anawar and Ryusuke Hatano

Received: 27 January 2021

Accepted: 22 March 2021

Published: 28 March 2021

Publisher's Note: MDPI stays neutral with regard to jurisdictional claims in published maps and institutional affiliations.

Copyright: (c) 2021 by the authors. Licensee MDPI, Basel, Switzerland. This article is an open access article distributed under the terms and conditions of the Creative Commons Attribution (CC BY) license (https:/ / creativecommons.org/licenses/by/ $4.0 /)$.
1 Academic Unit of Garanhuns, Federal University of Agreste of Pernambuco, Garanhuns, PE 55292-270, Brazil; goesmariacc@gmail.com (M.d.C.C.d.G.); erika.valente@ufape.edu.br (É.V.d.M.); camila.barros@ufape.edu.br (M.C.d.B.S.L.); vanilson.silva@ufape.edu.br (V.P.d.S.)

2 Laboratory for the Study of Soil-Agrosystem-Hydrosystem Interactions, French National Research Institute for Sustainable Development, 34060 Montpellier, France; claude.hammecker@ird.fr

3 Department of Nuclear Energy, Federal University of Pernambuco, Recife, PE 50740-540, Brazil; antonio.antonino@ufpe.br (A.C.D.A.); esampaio@ufpe.br (E.V.d.S.B.S.)

4 Academic Unit of Serra Talhada, Federal Rural University of Pernambuco, Serra Talhada, PE 56909-535, Brazil; eduardo.ssouza@ufrpe.br

5 Department of Biological and Agricultural Engineering, Texas A\&M University, College Station, TX 77843-3127, USA; rodolfo.souza@tamu.edu

* Correspondence: romualdo.lima@ufape.edu.br; Tel.: +55-87-3764-5529

\begin{abstract}
Common bean is usually cropped under rainfed conditions and in soils with low $\mathrm{pH}$ and water retention, in the sub-humid and semiarid regions of Brazil. To improve soil conditions, smallholder farmers commonly use cattle manure. However, manure is available in limited amounts, insufficient to fertilize all cropping areas. Thus, other amendments, such as poultry manure (PM) and biochar $(\mathrm{BC})$, have been proposed to increase soil water retention and $\mathrm{pH}$. We evaluated the effects of $B C\left(10,20\right.$, and $40 \mathrm{tha}^{-1}$; BC10, BC20, and BC40, respectively), PM (5 $\mathrm{t} \mathrm{ha}^{-1}$; PM), the combination of both amendments (BC10 + PM, BC20 + PM, and BC40 + PM) and an absolute control (Control), with no amendment, on soil physical, chemical, and biological properties, and on common bean water use efficiency (WUE) and yield. The treatments had no effects on total organic carbon, cation exchange capacity, microbial biomass carbon, soil physical properties, and evapotranspiration. Treatment combination BC $\left(10 \mathrm{t} \mathrm{ha}^{-1}\right)+\mathrm{PM}\left(5 \mathrm{tha}^{-1}\right)$ significantly improved phosphorus concentration, enzymatic activities, WUE, and bean yield in this one-year experiment and it can be a viable management practice for smallholder farmers in the Brazilian sub-humid region. However, further investigations are required to study the long-term field effects of the best performing soil amendments.
\end{abstract}

Keywords: biochar; poultry manure; evapotranspiration; sustainable agriculture; soil health

\section{Introduction}

Population growth is increasing the demand for agricultural products [1,2], which can increase land degradation due to intensive agricultural use, often of marginal areas. Land degradation impacts many soil physical, chemical, and biological properties, including organic carbon [3,4], hydraulic conductivity [5,6], bulk density, runoff and erosion [6,7], nutrient availability, microbial biomass, and enzyme activities [8,9]. Land degradation is a worldwide problem, particularly in sub-humid, semiarid, and arid regions $[1,10]$. In these regions, water shortage, due to rainfall scarcity and irregular temporal and spatial distribution, exacerbates the difficulty in maintaining and/or increasing agricultural yield. 
In the sub-humid and semiarid regions of Brazil, besides water problems, there are large areas with low fertility and low water retention capacity soils [11,12]. Cattle manure is commonly added to increase total organic carbon content (TOC) and nutrient availability, to reduce acidity, and to raise the water retention capacity. However, cattle manure availability is insufficient to fertilize all cropping areas and it usually has low mineral nutrient concentrations, due to the system of extensive cattle raising [13].

The intensification of poultry production is providing another manure source [14,15], but this manure is not traditionally used in the region [13]. As other manures, the concentration of nutrients is relatively low, implying high costs of transportation and distribution, and the added organic matter is usually mineralized within only a few cropping seasons. Therefore, applications have to be frequently repeated to maintain soil productivity [16].

An alternative or complementary organic amendment is biochar (BC) [1,16-20]. BC is the result of the pyrolysis process of different biomass types, and it is rich in carbon [21], although lower in nutrients than manures [22,23]. Positive effects of BC application on soil physical, chemical, and biological properties and crop yield have been reported in many studies [18,24-27], although other studies show none or unfavorable consequences on soil properties and crop yield [28-31]. The amelioration of soil properties, such as decreased soil acidity and increased of nutrient concentrations and soil water retention, can be responsible for increased crop yields in soils amended with biochar $[18,20,24-26]$.

The scarcity of scientific reports in the study area that combined BC and poultry manure (PM) and simultaneously evaluated soil physical, chemical, and biological properties plus crop yields led to the establishment of the present work. To our knowledge, this is the first work to combine all these evaluation in a field experiment of a common bean crop under rainfed conditions in a tropical sub-humid climate. We hypothesized that the combination of BC and PM improves bean yield and soil properties in relation to the amendment with the isolated organic amendments.

\section{Materials and Methods}

\subsection{Study Site and Treatments}

One field experiment was conducted at the Research Farm, Federal Rural University of Pernambuco, Garanhuns municipality $\left(08^{\circ} 48^{\prime} 34.2^{\prime \prime}\right.$ S, $36^{\circ} 24^{\prime} 29.3^{\prime \prime}$ W), Pernambuco state, Brazil, during the cropping season of 2019. The experiment was intended to be conducted for two more years, but the planting in 2020 was not made due to the Covid pandemic. According to Köppen's classification system, the climate of the area is As' [32], with annual rainfall averaging $918 \mathrm{~mm}$, concentrated between April and August [33]. The predominant soil is Acrisol [34]. The soil texture of the studied site was determined according to Donagemma et al. [35], and is shown in Table 1.

Table 1. Soil texture of topsoil in the experimental area.

\begin{tabular}{cc}
\hline Characteristic & Granulometric Fractions \\
\hline Sand $\left(\mathrm{g} \mathrm{kg}^{-1}\right)$ & 586 \\
Silt $\left(\mathrm{g} \mathrm{kg}^{-1}\right)$ & 94 \\
Clay $\left(\mathrm{g} \mathrm{kg}^{-1}\right)$ & 320 \\
Textural class & Sandy clay loam \\
\hline
\end{tabular}

The experiment had eight treatments, arranged in a completely randomized block design, with three replicates, totalizing 24 plots. Each plot was $3 \mathrm{~m} \times 4 \mathrm{~m}\left(12 \mathrm{~m}^{2}\right)$. Blocks were $2 \mathrm{~m}$ apart and plots were $1 \mathrm{~m}$ apart. The treatments were $\mathrm{BC}$, applied in doses equivalent to 10 (BC10), 20 (BC20), and 40 (BC40) $\mathrm{t} \mathrm{ha}^{-1}$; $\mathrm{PM}$ at $5 \mathrm{t} \mathrm{ha}^{-1}$; this same dose of PM combined with BC, also in doses of $10(\mathrm{BC} 10+\mathrm{PM}), 20(\mathrm{BC} 20+\mathrm{PM})$, and $40(\mathrm{BC} 40+$ $\mathrm{PM}) \mathrm{t} \mathrm{ha}^{-1}$, and an absolute control (Control), with no amendment. These doses are in the range commonly applied in Brazil and other countries $[14,18,22,23,26]$.

The BC was obtained by oxygen free pyrolysis in traditional charcoal producing kilns, fed with hardwood, such as Anacardium occidentale L. and Byrsonima crassifolia (L.). The tem- 
perature inside the kiln, monitored with a thermocouple, averaged $500-550{ }^{\circ} \mathrm{C}$ for $24-48 \mathrm{~h}$. The BC was ground, sieved to $2 \mathrm{~mm}$, and analyzed (Table 2) for $\mathrm{pH}$, TOC, phosphorus $(\mathrm{P})$, potassium $(\mathrm{K})$, calcium $(\mathrm{Ca})$, magnesium $(\mathrm{Mg})$, and sodium $(\mathrm{Na})$ concentrations, using the methodology recommended by Donagemma et al. [35]. The PM was obtained from local poultry producers and analyzed for $\mathrm{pH}, \mathrm{TOC}$, and nitrogen $(\mathrm{N}), \mathrm{P}, \mathrm{K}, \mathrm{Ca}$, and $\mathrm{Mg}$ concentrations (Table 2), using the methodology recommended by Donagemma et al. [35].

Table 2. Selected chemical characteristics of the biochar and poultry manure used in the experiment.

\begin{tabular}{cccc}
\hline Characteristic & Biochar & Characteristic & Poultry Manure \\
\hline $\mathrm{pH}$ & 9.8 & $\mathrm{pH}$ & 8.9 \\
Total organic carbon, $\mathrm{g} \mathrm{kg}^{-1}$ & 543 & Total organic carbon, \% & 23.7 \\
Phosphorus, mg kg-1 & 2.0 & Phosphorus, \% & 4.8 \\
Potassium, $\mathrm{cmol}_{\mathrm{c}} \mathrm{kg}^{-1}$ & 3.9 & Potassium, \% & 4.3 \\
Calcium, $\mathrm{cmol}_{\mathrm{c}} \mathrm{kg}^{-1}$ & 2.8 & Calcium, \% & 1.5 \\
Magnesium, $\mathrm{cmol}_{\mathrm{c}} \mathrm{kg}^{-1}$ & 1.1 & Magnesium, \% & 1.0 \\
Sodium, $\mathrm{cmol}_{\mathrm{c}} \mathrm{kg}^{-1}$ & 0.6 & Nitrogen, \% & 2.4 \\
\hline
\end{tabular}

The BC and the PM were spread evenly on the soil surface and incorporated to a depth of approximately $10 \mathrm{~cm}$, using a hand hoe, on 4 May 2019. Ten days later, common bean (Phaseolus vulgaris L. cv. BRS Netuno) was sown placing three seeds in the bottom of holes opened by hoe, spaced by $20 \mathrm{~cm}$, along rows spaced by $25 \mathrm{~cm}$. Manual weeding was done once a month until harvesting, on 14 August (90 days after sowing). No inorganic fertilizer or irrigation was applied during the course of the experiment. At harvest, all the aboveground biomass was cut in a $2 \mathrm{~m}^{2}$ area in each plot and separated into straw and pods. The pods were dried, manually threshed, and the grains were weighed on a precision scale. The grain yield was adjusted to a humidity of 13\% [36].

\subsection{Determination of Soil Physical, Chemical, and Biological Properties}

After harvest, three undisturbed and three disturbed soil samples were collected from each plot to determine physical, chemical, and biological properties. The samples were collected from the superficial soil layer $(0-10 \mathrm{~cm}$ depth), into which the organic amendments were incorporated and where larger effects were expected. The undisturbed samples were collected using $5-\mathrm{cm}$ diameter and $5-\mathrm{cm}$ high cylinders $\left(98 \mathrm{~cm}^{3}\right.$ volume). They were used to evaluate bulk density (BD), total porosity (TP), field capacity (FC), permanent wilting point (PWP), and plant available water (PAW). Total porosity was calculated from BD values, assuming a particle density of $2.65 \mathrm{Mg} \mathrm{m}^{-3}$. Field capacity and PWP were obtained by the pressure plate method, using pressures of 0.01 and $1.5 \mathrm{MPa}$, respectively, and PAW was calculated as FC minus PWP [35].

The disturbed soil samples were air-dried and sieved using a 2-mm sieve and analyzed for $\mathrm{pH}, \mathrm{TOC}, \mathrm{P}$, and $\mathrm{K}$ concentrations, and cation exchange capacity (CEC), following the methodologies described by Donagemma et al. [35]. Total organic carbon was determined by the $\mathrm{C}$ oxidation method, with potassium dichromate followed by titration of the remaining $\mathrm{Cr}_{2} \mathrm{O}_{7}{ }^{2-}$ with ammonium iron (II) sulfate [37]. Phosphorus, $\mathrm{Na}^{+}$, and $\mathrm{K}^{+}$were extracted using Mehlich's solution $1\left(\mathrm{H}_{2} \mathrm{SO}_{4} 0.125 \mathrm{~mol} \mathrm{~L}^{-1}+\mathrm{HCl} 0.5 \mathrm{~mol} \mathrm{~L}^{-1}\right)$. Phosphorus was determined by colorimetry and $\mathrm{Na}^{+}$and $\mathrm{K}^{+}$by flame photometry [35]. Calcium $\left(\mathrm{Ca}^{2+}\right), \mathrm{Mg}^{2+}$, and $\mathrm{Al}^{3+}$ were extracted with a $\mathrm{KCl} 1.0 \mathrm{~mol} \mathrm{~L}^{-1}$ solution; the first two were determined using atomic absorption spectrometry and $\mathrm{Al}^{3+}$ was determined by titration with $\mathrm{NaOH} 0.025 \mathrm{~mol} \mathrm{~L}^{-1}$, using bromothymol blue as an indicator [35]. Potential acidity $\left(\mathrm{H}+\mathrm{Al}^{3+}\right)$ was determined using calcium acetate $\left(\mathrm{Ca}\left(\mathrm{CH}_{3} \mathrm{OO}\right)_{2} \mathrm{H}_{2} \mathrm{O}\right)$ at $\mathrm{pH} 7.0$ [35] and CEC was calculated as the sum of bases $\left(\mathrm{Ca}^{2+}+\mathrm{Mg}^{2+}+\mathrm{K}^{+}+\mathrm{Na}^{+}\right)$plus $\mathrm{H}+\mathrm{Al}^{3+}$ [35].

Microbial biomass carbon (MBC) was determined using the methodology of irradiation [38], in which $20 \mathrm{~g}$ of irradiated and non-irradiated soil samples were extracted with $80 \mathrm{~mL}$ of $\mathrm{K}_{2} \mathrm{SO}_{4} 0.5 \mathrm{M}$ [39] and the C content was determined by colorimetry [40]. Enzymatic activities were determined estimating the gene expression of the main pro- 
cesses related to acidic phosphatase (P. Aci) and urease (Ure), according to the colorimetric analysis of the products released by the samples subjected to incubation in an adequate substrate (Sigma-Aldrich). The P. Aci was estimated according to the methodology of Eivazi and Tabatabai [41], and the Ure activity the methodology of Kandeler and Gerber [42]. Product absorbance was measured using a spectrophotometer (Libra S22, Biochrom, Cambridge, UK).

\subsection{Determination of Evapotranspiration, Yield, and Water Use Efficiency}

Evapotranspiration (ET) was obtained as the residual term of Equation (1), according to Silva et al. [43]:

$$
\Delta S=P+I+C r-D \pm R-E T,
$$

where $P$ is rainfall $(\mathrm{mm}), I$ is irrigation $(\mathrm{mm}), C r$ is capillary rise $(\mathrm{mm}), D$ is deep drainage $(\mathrm{mm}), R$ is surface runoff $(\mathrm{mm}), E T$ is actual evapotranspiration $(\mathrm{mm})$, and $\Delta S$ is the change in soil water storage $(\mathrm{mm})$ which can be calculated as:

$$
\Delta S=S_{t 2}-S_{t 1}
$$

where $S_{t 2}$ and $S_{t 1}$ are the soil water storage at the final and initial times, respectively.

Considering that the soil water content was obtained for constant soil layers from the surface $(z=0)$ down to the bottom of the soil depth which was measured $(z=L)$, the storage soil moisture $(S)$ was determined as:

$$
S_{L}=\theta z,
$$

where $\theta$ is the average soil layer moisture $\left(\mathrm{m}^{3} \mathrm{~m}^{-3}\right)$ and $\mathrm{z}$ is the thickness of the soil layer ( $\mathrm{mm}$ ).

In the field, time domain reflectometry (TDR) automatic sensors (CS616, Campbell Scientific Inc., Logan, UT, USA) were installed from 0 to $0.30-\mathrm{m}$ depth to measure the soil water content. The data were read every minute and stored every $30 \mathrm{~min}$ in dataloggers (CR 1000, Campbell Scientific Inc., Logan, UT, USA).

In the experiment, the irrigation $(I)$ was null and the surface runoff was obtained by rainfall data, according to Souza et al. [44]. The flux $(q)$ of water crossing the bottom of the soil layer (deep drainage, $D$, or capillary rise, $C r$ ) was obtained as follows:

$$
q=-K(\theta) \nabla \psi_{t},
$$

where $K(\theta)$ is the soil hydraulic conductivity and $\nabla \psi_{t}$ is the vertical gradient of the total potential.

The van Genuchten [45] parametric functions were used to obtain the soil water retention function as:

$$
\theta\left(\psi_{m}\right)=\theta_{r}+\frac{\left(\theta_{s}-\theta_{r}\right)}{\left[1+\left(\alpha \psi_{m}\right)^{\mathrm{n}}\right]^{\mathrm{m}}},
$$

where $\theta_{r}$ and $\theta_{s}$ are residual and saturation soil water contents, respectively, in $\mathrm{m}^{3} \mathrm{~m}^{-3}$, $\psi_{m}$ is the soil matrix potential in $\mathrm{cm}$ of water, and $\alpha, \mathrm{n}$ and $\mathrm{m}$ are empirical constants.

The parameters for the water retention curves were obtained by fitting Equation (5) to experimental field and laboratory data. The hydraulic conductivity for unsaturated soil, $K(\theta)$, was determined as:

$$
K(\theta)=K_{s} S_{e}^{2}\left[1-\left(1-S e^{\frac{1}{m}}\right)^{m}\right],
$$

where $K_{S}$ is the saturated soil hydraulic conductivity, and $S_{e}$ is the effective soil water content:

$$
S e=\frac{\theta-\theta_{r}}{\theta_{s}-\theta_{r}},
$$


The water use efficiency (WUE) was obtained by Equation (8):

$$
W U E=\frac{Y}{E T}
$$

where $Y$ is the yield of bean $\left(\mathrm{kg} \mathrm{ha}^{-1}\right)$ that was measured in plots of $2 \mathrm{~m}^{2}$.

\subsection{Data Analysis}

The normality and homogeneity of variances were respectively tested by Shapiro-Wilk and Bartlett tests. However, because some variables did not present a normal distribution, the data were subjected to the Kruskal-Wallis non-parametric test. The medians were compared using the Dunn test at the 0.05 probability level, using the R software (version 4.0.3) [46]. Spearman correlation analyses were performed between yield and other variables using the $\mathrm{R}$ software (version 4.0.3) [46].

\section{Results}

The soil amendments had no significant effects on BD, TP, FC, PWP, PAW, TOC, and MBC and also no effect on ET (Table 3, Table 4, Table 5, Table 6). The ranges of values were typical of this soil class in the region, with special notice to the low TOC concentrations (3.6 to $4.4 \mathrm{~g} \mathrm{~kg}^{-1}$ ). The soil amendments had also no effect on soil $\mathrm{pH}$ and $\mathrm{P}$ concentration when compared to the absolute control, with exception of the treatments BC40 + PM and $\mathrm{BC} 10+\mathrm{PM}$, which significantly increased the $\mathrm{pH}$ and $\mathrm{P}$ concentration, respectively (Table 4). The soil amendments had no significant effects on K concentration and on CEC (Table 4). The treatments BC40, PM, and BC10 + PM had significant effects on P. Aci, and the treatments PM, BC10 + PM, and BC40 + PM on Ure enzymatic activities (Table 5), when compared to the absolute control. The treatments BC10 + PM and BC40 + PM had significant effects on WUE and especially on the bean yield, which was more than three times higher with the treatments BC10 + PM and BC40 + PM (Table 6), when compared to the absolute control.

Soil characteristic including $\mathrm{pH}, \mathrm{P}, \mathrm{WUE}, \mathrm{P}$. acid, and Ure were positively correlated with bean yield (Table 7). These correlated characteristics were those that were improved by the soil amendments.

Table 3. Effects of biochar (BC), applied at 10,20 or $40 \mathrm{t} \mathrm{ha}^{-1}$, and poultry manure (PM, $5 \mathrm{t} \mathrm{ha}^{-1}$ ) on soil physical properties.

\begin{tabular}{|c|c|c|c|c|c|}
\hline & Bulk Density & Total Porosity & Field Capacity & Permanent Wilting Point & Plant Available Water \\
\hline Treatments & $\mathrm{Mg} \mathrm{m}^{-3}$ & & & $\mathrm{~m}^{3} \mathrm{~m}^{-3}$ & \\
\hline Control & 1.21 & 0.54 & 0.20 & 0.16 & 0.04 \\
\hline BC10 & 1.19 & 0.55 & 0.18 & 0.14 & 0.04 \\
\hline $\mathrm{BC} 20$ & 1.22 & 0.54 & 0.20 & 0.16 & 0.04 \\
\hline $\mathrm{BC} 40$ & 1.25 & 0.53 & 0.20 & 0.17 & 0.03 \\
\hline PM & 1.25 & 0.53 & 0.19 & 0.15 & 0.04 \\
\hline $\mathrm{BC} 10+\mathrm{PM}$ & 1.13 & 0.58 & 0.20 & 0.16 & 0.04 \\
\hline $\mathrm{BC} 20+\mathrm{PM}$ & 1.23 & 0.54 & 0.21 & 0.16 & 0.05 \\
\hline $\mathrm{BC} 40+\mathrm{PM}$ & 1.21 & 0.54 & 0.21 & 0.17 & 0.04 \\
\hline $\mathrm{Chi}^{2}$ & 7.66 & 7.99 & 2.92 & 2.38 & 1.92 \\
\hline$p$-value ${ }^{a}$ & 0.36 & 0.33 & 0.89 & 0.95 & 0.96 \\
\hline
\end{tabular}

$\mathrm{a}=p$-value of the Kruskal-Wallis test. 
Table 4. Effects of biochar (BC), applied at 10,20 or $40 \mathrm{tha}^{-1}$, and poultry manure (PM, $5 \mathrm{tha}{ }^{-1}$ ) on soil chemical properties.

\begin{tabular}{|c|c|c|c|c|c|}
\hline & $\mathrm{pH}$ & Total Organic Carbon & Phosphorus & Potassium & Cation Exchange Capacity \\
\hline Treatments & & $\mathrm{g} \mathrm{kg}^{-1}$ & $\mathrm{mg} \mathrm{kg}^{-1}$ & $\mathrm{cmol}_{\mathrm{c}} \mathrm{kg}^{-1}$ & $\mathrm{cmol}_{\mathrm{c}} \mathrm{kg}^{-1}$ \\
\hline Control & 4.93 & 3.60 & 0.60 & 0.11 & 3.02 \\
\hline BC10 & 5.33 & 4.17 & 2.67 & 0.13 & 3.08 \\
\hline BC20 & 5.41 & 4.39 & 2.42 & 0.39 & 3.17 \\
\hline BC40 & 5.76 & 3.77 & 2.47 & 0.23 & 3.07 \\
\hline PM & 5.49 & 3.81 & 17.00 & 0.21 & 3.22 \\
\hline $\mathrm{BC} 10+\mathrm{PM}$ & 5.80 & 3.95 & 36.08 * & 0.34 & 3.59 \\
\hline $\mathrm{BC} 20+\mathrm{PM}$ & 5.76 & 3.88 & 23.22 & 0.27 & 3.37 \\
\hline $\mathrm{BC} 40+\mathrm{PM}$ & 6.04 * & 3.56 & 17.37 & 0.25 & 3.00 \\
\hline $\mathrm{Chi}^{2}$ & 15.00 & 2.19 & 18.92 & 8.52 & 3.08 \\
\hline$p$-value ${ }^{\text {a }}$ & 0.04 & 0.95 & 0.01 & 0.29 & 0.88 \\
\hline
\end{tabular}

a $=p$-value of the Kruskal-Wallis test; * represents significant difference at alpha 0.05, by Dunn's test.

Table 5. Effects of biochar (BC), applied at 10, 20 or $40 \mathrm{t} \mathrm{ha}^{-1}$, and poultry manure $\left(\mathrm{PM}, 5 \mathrm{t} \mathrm{ha}{ }^{-1}\right)$ on soil biological properties.

\begin{tabular}{|c|c|c|c|}
\hline & MBC & Acidic Phosphatase & Urease \\
\hline Treatments & $\mathrm{g} \mathrm{kg}^{-1}$ & $\mu g$ p-Nitrof. $g^{-1}$ Soil $^{-1}$ & $\mu \mathrm{gNH}_{4}-\mathrm{Ng}^{-1} \mathrm{dwt} 2 \mathrm{~h}^{-1}$ \\
\hline Control & 97.67 & 2.36 & 0.27 \\
\hline BC10 & 92.71 & 2.59 & 0.66 \\
\hline BC20 & 151.04 & 2.88 & 0.37 \\
\hline $\mathrm{BC} 40$ & 158.40 & $3.11 *$ & 0.54 \\
\hline PM & 114.33 & $3.12 *$ & $1.11^{*}$ \\
\hline $\mathrm{BC} 10+\mathrm{PM}$ & 141.00 & 3.15 * & 1.12 * \\
\hline $\mathrm{BC} 20+\mathrm{PM}$ & 202.73 & 2.83 & 0.87 \\
\hline $\mathrm{BC} 40+\mathrm{PM}$ & 205.30 & 2.77 & $1.18 *$ \\
\hline $\mathrm{Chi}^{2}$ & 9.77 & 14.86 & 18.63 \\
\hline$p$-value ${ }^{a}$ & 0.20 & 0.04 & 0.01 \\
\hline
\end{tabular}

Table 6. Effects of biochar (BC), applied at 10, 20 or $40 \mathrm{t} \mathrm{ha}^{-1}$, and poultry manure (PM, $5 \mathrm{t} \mathrm{ha}^{-1}$ ) on evapotranspiration, yield, and water use efficiency of common bean and on economic expense, income, and benefits.

\begin{tabular}{|c|c|c|c|c|c|c|}
\hline & Evapotranspiration & Yield & Water Use Efficiency & Expense & Income & Benefit \\
\hline Treatments & $\mathrm{mm}$ & $\mathrm{kg} \mathrm{ha}^{-1}$ & $\mathrm{~kg} \mathrm{ha}^{-1} \mathrm{~mm}^{-1}$ & & US\$ & \\
\hline Control & 350 & 553 & 1.6 & 270 & 691 & 421 \\
\hline $\mathrm{BC} 10$ & 349 & 911 & 2.6 & 2270 & 1139 & -1131 \\
\hline BC20 & 347 & 1124 & 3.2 & 4270 & 1405 & -2865 \\
\hline BC40 & 345 & 1379 & 4.0 & 8270 & 1724 & -6546 \\
\hline PM & 354 & 1828 & 5.2 & 460 & 2285 & 1825 \\
\hline $\mathrm{BC} 10+\mathrm{PM}$ & 350 & $2515 *$ & $7.2 *$ & 2460 & 3144 & 684 \\
\hline $\mathrm{BC} 20+\mathrm{PM}$ & 347 & 1799 & 5.2 & 4460 & 2249 & -2211 \\
\hline $\mathrm{BC} 40+\mathrm{PM}$ & 349 & $2398 *$ & $6.9 *$ & 8460 & 2998 & -5463 \\
\hline $\mathrm{Chi}^{2}$ & 3.13 & 17.79 & 18.05 & & & \\
\hline$p$-value ${ }^{a}$ & 0.87 & 0.01 & 0.01 & & & \\
\hline
\end{tabular}

\footnotetext{
${ }^{\mathrm{a}}=p$-value of the Kruskal-Wallis test; ${ }^{*}$ represents significant difference at alpha 0.05 , by Dunn's test.
} 
Table 7. Spearman's rank-order correlation coefficient between yield of common bean and $\mathrm{pH}$, phosphorus (P) and potassium (K) concentrations, cation exchange capacity (CEC), total organic carbon content (TOC), evapotranspiration (ET), water use efficiency (WUE), field capacity (FC), permanent wilting point (PWP), bulk density (BD), total porosity (TP), microbial biomass carbon (MBC), and acidic phosphatase (P. acid) and urease (Ure) activities. $(n=8)$.

\begin{tabular}{cccc}
\hline Property & Coefficient & Property & Coefficient \\
\hline pH & $0.8809^{* *}$ & FC & 0.1557 \\
P & $0.7143^{*}$ & PWP & 0.2994 \\
K & 0.5238 & BD & -0.3832 \\
CEC & 0.4048 & TP & 0.3832 \\
TOC & 0.0964 & MBC & 0.5952 \\
ET & 0.0491 & P. acid & $0.6905^{*}$ \\
WUE & $0.9940^{* *}$ & Ure & $0.9048^{* *}$ \\
\hline
\end{tabular}

*,** represent significant correlation at alpha 0.5 and 0.01 , respectively.

\section{Discussion}

The fact that the application of $\mathrm{BC}$ and $\mathrm{PM}$, isolated or combined, did not enhance the soil physical properties, including BD, TP, FC, PWP, and PAW, could be partly attributed to the texture of the soil in the experimental area. The effects of these organic amendments are greater in coarse-textured soils [27,47] and the soil in the experimental area is classified as a sandy clay loam (Table 1). Adekiya et al. [22] found positive effects of BC and PM on physical properties of a Luvisol with $76 \%$ sand and Agbede et al. [23] found that BC and PM treatments significantly reduced BD and increased TP and soil water content, also in a Luvisol, but with $92 \%$ of sand. The effects of the amendments are also influenced by their particle size and the $2 \mathrm{~mm}$ used in the current study may have been too coarse. Głab et al. [48] reported positive effects on soil physical attributes using particle size smaller than $0.5 \mathrm{~mm}$. The short period (three months) between application of the amendments and soil sample may have also precluded more extensive changes in these soil properties [49,50]. Most studies describing positive soil structure evolution with BC amendment claim better soil aggregation due to enhanced microbial activity, the presence of mycorrhizal hyphae [50,51]. Finally, the applied amendments correspond to relatively small proportions of the total soil volume and mass of the sampled layer and, consequently, their influence on physical properties tends to be limited.

$\mathrm{BD}$ and TP are associated with soil texture and also with soil structure, i.e., aggregation and stability, which are related with TOC [52]. Yang and Lu [53] found that the soil aggregation and stability could be partly related to the increased TOC in the BC-amended soils. However, in our study, the TOC was not significantly influenced by the application of the soil amendments (Table 4); thus, this can also explain the absence of significant effects of the amendments on BD and TP in this short-term field experiment.

The soil $\mathrm{pH}$ and $\mathrm{P}$ concentration, as well as enzyme activities were positively affected by the application of the soil amendments (Tables 4 and 5), contrasting to the absence of effects on the physical properties. These effects are particularly important in acidic soils with low initial soil fertility status. Du et al. [54] reported that PM application increases soil $\mathrm{pH}$ and Adekiya et al. [22] and Agbede et al. [23] argued that manure increases soil $\mathrm{pH}$ due to ion exchange reactions which occur when the terminal $\mathrm{OH}^{-}$of $\mathrm{Al}^{3+}$ or $\mathrm{Fe}^{2+}$ hydroxyl oxides are replaced by organic anions, such as malate, citrate, and tartrate, originated from the decomposition of the manure. $\mathrm{BC}$ also increases soil $\mathrm{pH}$ due to its high $\mathrm{pH}(9.8)$, caused by the alkaline ash in its composition [18], which includes $\mathrm{Ca}$ and $\mathrm{Mg}$ oxides and $\mathrm{K}$ oxides, hydroxides, and carbonates [55].

The decrease in soil acidity may have promoted an increase in P availability (Table 4). Glaser and Lehr [56] found that the addition of BC significantly increased P availability, up to a factor of 4.6, independently of the woodstock used for BC production. The BC liming and fertilization effects, especially on nutrient-poor and acidic soils, results in higher crop yields [57], as obtained in our study. Du et al. [54] performed a meta-analysis to determine 
the effect of several manure types (e.g., pig, cattle, sheep, cow, chicken, livestock and farmyard) on soil properties and found that manure application also increases available $\mathrm{P}$ and $\mathrm{K}$, promoting higher yields, more pronounced under warm and humid climates. The high correlation of the soil chemical and biological properties with yield indicates that the improvement in these properties may be partially responsible for the yield increase. The increase in $\mathrm{pH}$ and in nutrient availability may have also been contributed to the alteration in the Ure and P. acid activities, which are crucial for soil health due their role in organic matter decomposition, being considered the most sensitive indicator of soil changes [58].

The most important effect certainly was the increase in bean yield (Table 5). The average bean yield in this study region is low, around $900 \mathrm{~kg} \mathrm{ha}^{-1}$ [59], and it is attributed to the sandy soils where the culture prevails, which have low fertility and low water retention capacity [11]. The combined application of PM and BC increased the yield by $355 \%$. In conjunction with the low income of farmers, the low availability of cattle manure [13], and the good availability of PM and of agricultural wastes for the production of $\mathrm{BC}[18,60]$, the application of this combination can be a viable alternative to increase bean yield in the region.

The production costs of one hectare of bean, amended with $5 \mathrm{t} \mathrm{ha}^{-1}$ of PM, in the study region, are approximately $\$ 460$ [59], and considering that the price of bean is $\$ 1.25 \mathrm{~kg}^{-1}$, the application of PM would have a return of approximately $\$ 1800 \mathrm{ha}^{-1}$. The BC cost is variable, but considering the value of $\$ 200$ ton $^{-1}$ [61], the treatment $\mathrm{BC} 10+\mathrm{PM}$ would have a return of approximately $\$ 680 \mathrm{ha}^{-1}$, i.e., lower than that of PM alone. However, as $\mathrm{BC}$ is a source of recalcitrant carbon with a long mean residence time (several decades to several centuries) [21], it can promote positive effects on soil properties for many years.

\section{Conclusions}

The use of biochar (BC) and poultry manure (PM) had contrasted consequences on soil properties. Soil properties like BD, water holding capacity or CEC were unaffected by the amendment of $B C$ in the application rates chosen in this study $\left(10,20,40 \mathrm{tha}^{-1}\right)$. Different amounts of $\mathrm{BC}$ amendments or longer experimental periods might have had more significant impacts and further investigations are recommended to study long-term effects. However, this one-year field experiment demonstrated the efficiency of the combination of $\mathrm{BC}$ and $\mathrm{PM}$ amendments in improving soil chemical and biological properties. The combined application of $10 \mathrm{tha}^{-1}$ of $\mathrm{BC}$ and $5 \mathrm{tha}^{-1}$ of PM can be a viable management practice for smallholder farmers in the Brazilian sub-humid region since it increases $\mathrm{P}$ concentration, enzymatic activities, and water use efficiency and, particularly, it increases yields compared to the application of either BC or PM alone.

Author Contributions: Conceptualization, J.R.d.S.L., M.d.C.C.d.G., and A.C.D.A.; methodology, M.d.C.C.d.G., V.P.d.S., and M.C.d.B.S.L.; software, E.S.d.S. and R.S.; formal analysis, J.R.d.S.L., R.S., E.S.d.S., E.V.d.S.B.S., and C.H.; investigation, M.d.C.C.d.G., É.V.d.M., V.P.d.S., and M.C.d.B.S.L.; resources, A.C.D.A. and J.R.d.S.L.; writing—original draft preparation, J.R.d.S.L., É.V.d.M., E.V.d.S.B.S., and C.H.; writing-review and editing, J.R.d.S.L., É.V.d.M., E.V.d.S.B.S., A.C.D.A., R.S., E.S.d.S., and C.H.; funding acquisition, A.C.D.A. and J.R.d.S.L. All authors have read and agreed to the published version of the manuscript.

Funding: This research was funded by National Observatory of Water and Carbon Dynamics in the Caatinga Biome (INCT: NOWCBCB); by National Council for Scientifc and Technological Development (CNPq), grant numbers (465764/2014-2, 409990/2018-3, 307335/2017-8, 310537/2017-7, 313493/2020-0), by Coordenação de Aperfeiçoamento de Pessoal de Nível Superior-Brasil (CAPES), grant numbers (Finance Code 001; 88881.318207/2019-01/PrInt, 88887.136369/2017-00), and Fundação de Amparo à Ciência e Tecnologia do Estado de Pernambuco (FACEPE), grant numbers [APQ-0532-5.01/14; APQ-0498-3.07/17]. The APC was funded by National Observatory of Water and Carbon Dynamics in the Caatinga Biome (INCT: NOWCBCB).

Institutional Review Board Statement: Not applicable.

Informed Consent Statement: Not applicable. 
Data Availability Statement: The data that support the findings of this study are available from the corresponding author, (JRSL), upon reasonable request.

Conflicts of Interest: The authors declare no conflict of interest.

\section{References}

1. Sadaf, J.; Shah, G.A.; Shahzad, K.; Ali, N.; Shahid, M.; Ali, S.; Hussain, R.A.; Ahmed, Z.I.; Traore, B.; Ismail, I.M.I.; et al. Improvements in wheat productivity and soil quality can accomplish by co-application of biochars and chemical fertilizers. Sci. Total Environ. 2017, 607-608, 715-724. [CrossRef]

2. Wang, D.; Fonte, S.J.; Parikh, S.J.; Six, J.; Scow, K.M. Biochar additions can enhance soil structure and the physical stabilization of $\mathrm{C}$ in aggregates. Geoderma 2017, 303, 110-117. [CrossRef]

3. Barros, J.A.; Medeiros, E.V.; Costa, D.P.; Duda, G.P.; Lima, J.R.S.; Santos, U.J.; Antonino, A.C.D.; Hammecker, C. Human disturbance affects enzyme activity, microbial biomass and organic carbon in tropical dry sub-humid pasture and forest soils. Arch. Agron. Soil. Sci. 2019, 65. [CrossRef]

4. Santos, U.J.; Medeiros, E.V.; Duda, G.P.; Marques, M.C.; Souza, E.S.; Brossard, M.; Hammecker, C. Land use changes the soil carbon stocks, microbial biomass and fatty acid methyl ester (FAME) in Brazilian semiarid area. Arch. Agron. Soil Sci. 2019, 65, 755-769. [CrossRef]

5. $\quad$ Oliveira, J.A., Jr.; Souza, E.S.; Corrêa, M.M.; Lima, J.R.S.; Souza, R.M.S.; Filho, L.A.S. Variabilidade espacial de propriedades hidrodinâmicas de um Neossolo Regolítico sob pastagem e caatinga. Rev. Bras. Eng. Agric. Amb. 2014, 18, 631-639. [CrossRef]

6. Leite, P.A.M.; Souza, E.S.; Santos, E.S.; Gomes, R.J.; Cantalice, J.R.B.; Wilcox, B.P. The influence of forest regrowth on soil hydraulic properties and erosion in a semi-arid region of Brazil. Ecohydrology 2018, 11, e1910. [CrossRef]

7. Cantalice, J.R.B.; Silveira, F.P.M.; Singh, V.P.; Silva, Y.J.A.B.; Cavalcante, D.M.; Gomes, C. Interrill erosion and roughness parameters of vegetation in rangelands. Catena 2017, 148, 111-116. [CrossRef]

8. Ferreira, A.C.C.; Leite, L.F.C.; Araújo, A.S.F.; Eisenhauer, N.N. Land-use type effects on soil organic carbon and microbial properties in a semi-arid region of Northeast Brazil. Land Degrad. Dev. 2016, 27, 171-178. [CrossRef]

9. Santiago, A.; Recena, R.; Perea-Torres, F.; Moreno, M.T.; Carmona, E.; Delgado, A. Relationship of soil fertility to biochemical properties under agricultural practices aimed at controlling land degradation. Land Degrad. Dev. 2019, 30, 1121-1129. [CrossRef]

10. Vasu, D.; Tiwary, P.; Chandran, P.; Singh, S.K.; Ray, S.K.; Butte, P.; Parhad, V. A conceptual model of natural land degradation based on regressive pedogenesis in semiarid tropical environments. Land Degrad. Dev. 2018, 29, 2554-2567. [CrossRef]

11. Almeida, A.V.D.L.; Corrêa, M.M.; Lima, J.R.S.; Souza, E.S.; Santoro, K.R.; Antonino, A.C.D. Atributos Físicos, Macro e Micromorfológicos de Neossolos Regolíticos no Agreste Meridional de Pernambuco. Rev. Bras. Cienc. Solo 2015, 39, 1235-1246. [CrossRef]

12. Donagemma, G.K.; Freitas, P.L.; Balieiro, F.C.; Fontana, A.; Spera, S.T.; Lumbreras, J.F.; Viana, J.H.M.; Filho, J.C.A.; Santos, F.C.; Albuquerque, M.R.; et al. Caracterização, potencial agrícola e perspectivas de manejo de solos leves no Brasil. Pesq. Agropec. Bras. 2016, 51, 1003-1020. [CrossRef]

13. Garrido, M.S.; Menezes, R.S.C.; Sampaio, E.V.S.B.; Marques, T.R.R.; Olszevski, N. Accumulation and apparent recovery of N, P and $\mathrm{K}$ after the incorporation of gliricidia and manure in intercropping during the cultivation of corn-cowpea-cotton. Nutr. Cycl. Agroecosyst. 2017, 107, 187-196. [CrossRef]

14. Bohara, H.; Dodla, S.; Wang, J.J.; Darapuneni, M.; Acharya, B.S.; Magdi, S.; Pavuluri, K. Influence of poultry litter and biochar on soil water dynamics and nutrient leaching from a very fine sandy loam soil. Soil Tillage Res. 2019, 189, 44-51. [CrossRef]

15. Drózdz, D.; Wystalska, K.; Malinska, K.; Grosser, A.; Grobelak, A.; Kacprzak, M. Management of poultry manure in PolandCurrent state and future perspectives. J. Environ. Manag. 2020, 264, 110327. [CrossRef]

16. Uzoma, K.C.; Inoue, M.; Andry, H.; Fujimaki, H.; Zahoor, A.; Ni Shihara, E. Effect of cow manure biochar on maize productivity under sandy soil condition. Soil Use Manag. 2011, 27, 205-212. [CrossRef]

17. Al-Wabel, M.I.; Hussain, Q.; Usman, A.R.A.; Ahmad, M.; Abduljabbar, A.; Sallam, A.S.; Ok, Y.S. Impact of biochar properties on soil conditions and agricultural sustainability: A review. Land Degrad. Dev. 2018, 29, 2124-2161. [CrossRef]

18. Lima, J.R.S.; Silva, W.M.; Medeiros, E.V.; Duda, G.P.; Corrêa, M.M.; Filho, A.P.M.; Clermont-Dauphin, C.; Antonino, A.C.D.; Hammecker, C. Effect of biochar on physicochemical properties of a sandy soil and maize growth in a greenhouse experiment. Geoderma 2018, 319, 14-23. [CrossRef]

19. Irfan, M.; Hussain, Q.; Khan, K.S.; Akmal, M.; Ijaz, S.S.; Hayat, R.; Khalid, A.; Azeem, M.; Rashid, M. Response of soil microbial biomass and enzymatic activity to biochar amendment in the organic carbon deficient arid soil: A 2-year field study. Arab. J. Geosci. 2019, 12, 95. [CrossRef]

20. Saffari, N.; Hajabbasi, M.A.; Shirani, H.; Mosaddeghi, M.R.; Owens, G. Influence of corn residue biochar on water retention and penetration resistance in a calcareous sandy loam soil. Geoderma 2021, 383, 114734. [CrossRef]

21. Kavitha, B.; Reddy, P.V.L.; Kim, B.; Lee, S.S.; Pandey, S.K.; Kim, K.-H. Benefits and limitations of biochar amendment in agricultural soils: A review. J. Environ. Manag. 2018, 227, 146-154. [CrossRef]

22. Adekiya, A.O.; Agbede, T.M.; Aboyeji, C.M.; Dunsin, O.; Simeon, V.T. Effects of biochar and poultry manure on soil characteristics and the yield of radish. Sci. Hort. 2019, 243, 457-463. [CrossRef] 
23. Agbede, T.M.; Odoja, A.S.; Bayode, L.N.; Omotehinse, P.O.; Adepehin, I. Effects of biochar and poultry manure on soil properties, growth, yield and quality of cocoyam (Xanthosoma sagittifolium Schott) grown in sandy soil. Commun. Soil Sci. Plan. 2020, 51, 932-947. [CrossRef]

24. Agegnehu, G.; Bass, A.M.; Nelson, P.N.; Bird, M.I. Benefits of biochar, compost and biochar-compost for soil quality, maize yield and greenhouse gas emissions in a tropical agricultural soil. Sci. Total Environ. 2016, 543, 295-306. [CrossRef] [PubMed]

25. Silva, I.C.B.; Basílio, J.J.N.; Fernandes, L.A.; Colen, F.; Sampaio, R.A.; Frazão, L.A. Biochar from different residues on soil properties and common bean production. Sci. Agric. 2017, 74, 378-382. [CrossRef]

26. Tanure, M.M.C.; Costa, L.M.; Huiz, H.A.; Fernandes, R.B.A.; Cecon, P.R.; Pereira, J.D., Jr.; Luz, J.M.R. Soil water retention, physiological characteristics, and growth of maize plants in response to biochar application to soil. Soil Tillage Res. 2019, 192, 164-173. [CrossRef]

27. Razzaghi, F.; Obour, P.B.; Arthur, E. Does biochar improve soil water retention? A systematic review and meta-analysis. Geoderma 2020, 361, 114055. [CrossRef]

28. Borchard, N.; Siemens, J.; Ladd, B.; Möller, A.; Amelung, W. Application of biochars to sandy and silty soil failed to increase maize yield under common agricultural practice. Soil Tillage Res. 2014, 144, 184-194. [CrossRef]

29. Butnan, S.; Deenik, J.L.; Toomsan, B.; Antal, M.J.; Vityakona, P. Biochar characteristics and application rates affecting corn growth and properties of soils contrasting in texture and mineralogy. Geoderma 2015, 237-238, 105-116. [CrossRef]

30. Foster, E.J.; Hansen, N.; Wallenstein, M.; Cotrufo, M.F. Biochar and manure amendments impact soil nutrients and microbial enzymatic activities in a semi-arid irrigated maize cropping system. Agric. Ecosyst. Environ. 2016, 233, 404-414. [CrossRef]

31. Liu, C.; Liu, F.; Ravnskov, S.; Rubaek, G.H.; Sun, Z.; Andersen, M.N. Impact of wood biochar and its interactions with mycorrhizal fungi, phosphorus fertilization and irrigation strategies on potato growth. J. Agron. Crop Sci. 2017, 203, 131-145. [CrossRef]

32. Alvares, C.A.; Stape, J.L.; Sentelhas, P.C.; Gonçalves, J.L.M.; Sparovek, G. Köppen's climate classification map for Brazil. Meteorol. Z. 2013, 22, 711-728. [CrossRef]

33. Gondim, P.S.S.; Lima, J.R.S.; Antonino, A.C.D.; Hammecker, C.; Silva, R.A.B.; Gomes, C.A. Environmental control on water vapour and energy exchanges over grasslands in semiarid region of Brazil. Rev. Bras. Eng. Agric. Amb. 2015, 19, 3-8. [CrossRef]

34. IUSS Working Group WRB. World reference base for soil resources 2014, update 2015. In International Soil Classification System for Naming Soils and Creating Legends for Soil Maps; Food and Agriculture Organization of the United Nations: Rome, Italy, 2015; p. 203.

35. Donagemma, G.K.; Campos, D.V.B.; Calderano, S.B.; Teixeira, W.G.; Viana, J.H.M. Manual de Métodos de Análise do Solo, 2nd ed.; Embrapa Solos: Rio de Janeiro, Brazil, 2011.

36. Almeida, A.J.B.; Coelho, S.R.M.; Schoeninger, V.; Christ, D. Chemical changes in bean grains during storage in controlled conditions. Eng. Agric. 2017, 37, 529-540. [CrossRef]

37. Yeomans, J.C.; Bremner, J.M. A rapid and precise method for routine determination of organic carbon in soil. Commun. Soil Sci. Plant 1988, 19, 1467-1476. [CrossRef]

38. Mendonça, E.S.; Matos, E.S. Matéria Orgânica do Solo: Métodos de Análises; UFV: Viçosa, Brazil, 2005.

39. Tate, K.R.; Ross, D.J.; Feltham, C.W. A direct extraction method to estimate soil microbial C: Effects of experimental variables and some different calibration procedures. Soil Biol. Biochem. 1988, 20, 329-335. [CrossRef]

40. Bartlett, R.J.; Ross, D.S. Colorimetric determination of oxidizable carbon in acid soil solutions. Soil Sci. Soc. Am. J. 1988, 53, 191-192. [CrossRef]

41. Eivazi, F.; Tabatabai, M.A. Phosphatases in soils. Soil Biol. Biochem. 1977, 9, 167-172. [CrossRef]

42. Kandeler, E.; Gerber, H. Short-term assay of soil urease activity using colorimetric determination of ammonium. Biol. Fertil. Soils. 1988, 6, 68-72. [CrossRef]

43. Silva, R.A.B.; Lima, J.R.S.; Antonino, A.C.D.; Gondim, P.S.S.; Souza, E.S.; Barros, G.J., Jr. Balanço hídrico em Neossolo Regolítico cultivado com braquiária (Brachiaria decumbens Stapf). Rev. Bras. Cienc. Solo 2014, 38, 147-157. [CrossRef]

44. Souza, R.M.S.; Souza, E.S.; Antonino, A.C.D.; Lima, J.R.S. Balanço hídrico em área de pastagem no semiárido pernambucano. Rev. Bras. Eng. Agric. Amb. 2015, 19, 449-455. [CrossRef]

45. Van Genuchten, M.T.H. A closed-form equation for predicting the hydraulic conductivity of unsaturated soils. Soil Sci. Soc. Am. J. 1980, 44, 892-898. [CrossRef]

46. R Core Team. R: A Language and Environment for Statistical Computing; R Foundation for Statistical Computing: Vienna, Austria, 2013. Available online: http:/ / www.r-project.org/index.html (accessed on 20 November 2020).

47. Edeh, I.G.; Mašek, O.; Buss, W. A meta-analysis on biochar's effects on soil water properties-New insights and future research challenges. Sci. Total Environ. 2020, 714, 136857. [CrossRef]

48. Głąb, T.; Palmowska, J.; Zaleski, T.; Gondek, K. Effect of biochar application on soil hydrological properties and physical quality of sandy soil. Geoderma 2016, 281, 11-20. [CrossRef]

49. Mukherjee, A.; Lal, R. Biochar Impacts on Soil Physical Properties and Greenhouse Gas Emissions. Agronomy 2013, 3, 313-319. [CrossRef]

50. Burrell, L.D.; Zehetner, F.; Rampazzo, N.; Wimmer, B.; Soja, G. Long-term effects of biochar on soil physical properties. Geoderma 2016, 282, 96-102. [CrossRef]

51. Limwikran, T.; Kheoruenromne, I.; Suddhiprakarn, A.; Prakongkep, N.; Gilkes, R.J. Most Plant Nutrient Elements Are Retained by Biochar in Soil. Soil Syst. 2019, 3, 75. [CrossRef] 
52. Williams, D.M.; Blanco-Canqui, H.; Francis, C.A.; Galusha, T.D. Organic farming and soil physical properties: An assessment after 40 years. Agron. J. 2017, 109, 600-609. [CrossRef]

53. Yang, C.D.; Lu, S.G. Effects of five different biochars on aggregation, water retention and mechanical properties of paddy soil: A field experiment of three-season crops. Soil Tillage Res. 2021, 205, 104798. [CrossRef]

54. Du, Y.; Cui, B.; Zhang, Q.; Wang, Z.; Sun, J.; Niu, W. Effects of manure fertilizer on crop yield and soil properties in China: A meta-analysis. Catena 2020, 193, 104617. [CrossRef]

55. Han, L.; Sun, K.; Yang, Y.; Xia, X.; Li, F.; Yang, Z.; Xing, B. Biochar's stability and effect on the content, composition and turnover of soil organic carbon. Geoderma 2020, 364, 114184. [CrossRef]

56. Glaser, B.; Lehr, V.-I. Biochar effects on phosphorus availability in agricultural soils: A meta-analysis. Sci. Rep. 2019, 9, 9338. [CrossRef]

57. Jeffery, S.; Abalos, D.; Prodana, M.; Bastos, A.C.; van Groenigen, J.W.; Hungate, B.A.; Verheijen, F. Biochar boosts tropical but not temperate crop yields. Environ. Res. Lett. 2017, 12, 053001. [CrossRef]

58. Medeiros, E.V.; Duda, G.P.; Santos, L.A.R.; Lima, J.R.S.; Almeida-Cortêz, J.S.; Hammecker, C.; Lardy, L.; Cournac, L. Soil organic carbon, microbial biomass and enzyme activities responses to natural regeneration in a tropical dry region in Northeast Brazil. Catena 2017, 151, 137-146. [CrossRef]

59. Ribeiro, A.A.; Lima, J.R.S.; Souza, R.M.S.; Antonino, A.C.D.; Souza, E.S. Fluxos de carbono e evapotranspiração de feijão comum sob condições de sequeiro. Rev. Eng. Agric. 2018, 26, 229-239. [CrossRef]

60. Medeiros, E.V.; Moraes, M.C.H.S.; Costa, D.P.; Duda, G.P.; Silva, J.S.A.; Oliveira, J.B.; Lima, J.R.S.; Menezes, R.S.C.; Hammecker, C. Biochar and Trichoderma aureoviride applied to the sandy soil: Effect on soil quality and watermelon growth. Not. Bot. Horti Agrobot. Cluj Napoca 2020, 48, 735-751. [CrossRef]

61. Filiberto, D.; Gaunt, J.L. Practicality of Biochar Additions to Enhance Soil and Crop Productivity. Agriculture 2013, 3, 715-725. [CrossRef] 